\title{
An Empirical Investigation of Attitudes towards Wife- Beating among Men and Women in Seven Sub-Saharan African Countries
}

\author{
Manju Rani', SekharBonu' and Nafissatou Diop-Sidibe ${ }^{2}$
}

\begin{abstract}
This study used data from the demographic and health surveys (DHS) conducted between 1999 and 2001 in Benin, Ethiopia, Malawi, Mali, Rwanda, Uganda and Zimbabwe, to examine the magnitude and correlates of conditional acceptance of wife-beating among both men and women. Multivariate logistic regression models were fitted to investigate the independent association between different socio-demographic characteristics and acceptance of wife-beating. The acceptance of wife-beating for transgressing certain gender roles was widespread in all the countries. Men were consistently less likely to justify wife-beating than women. Household wealth and education emerged as strongest and most consistent negative predictors of acceptance of wife-beating among both men and women. Older men and women were less likely to justify wife-beating. Men and women in the polygamous union were more likely to accept wife-beating, though the association was not always significant. With the exception of Uganda, women working for pay were more likely to justify wife-beating than non-working women were. The results indicate that dominant social and cultural norms create images of "ideal" women among both men and women that include definition and widespread acceptance of gender roles as well as sanction use of force to enforce these gender roles. The State and its different institutions may fail to mitigate wife-beating, as sensitivity to objectively address wife-beating may be tellingly lacking. Though education, economic growth, etc, can reduce acceptance of wife-beating, the process may be too slow and too late to make a substantial difference in the near future. Proactive measures may be required to change attitudes towards wife-beating among both men and women. (AfrJ Reprod Health 2004; 8[3]:116136)
\end{abstract}

\section{RÉSUMÉ}

Etude empirique des attitudes envers la violence faite à la femme chez les hommes et les femmes dans sept pays africains subsahariens. Cette étude se sert des données tirées des enquêtes démographique et de santé (EDS) menées entre 1999 et 2001 à Benin City, en Ethiopie, au Malawi, au Rwanda, en Ouganda et au Zimbabwe afin d'examiner l'ampleur et les corrélats de l'acceptation de violence contre la femme aussi bien parmi les hommes que parmi les femmes. Des modèles de la régression logistique multifactoriels ont été établis pour vérifier l'association indépendante entre les caractéristiques démographiques différentes et l'acceptation de la violence contre la femme. L'acceptation de la violence contre la femme pour avoir transgressé certains rôles basés sur les rôles de genre était bien répandue dans les pays. Les hommes avaient régulièrement moins la possibilité de justifier l'agression contre la femme que les femmes. La richesse domestique et l'éducation comptaient parmi les indices négatifs les plus réguliers de l'acceptation de la violence chez les hommes et les femmes. Les hommes et les femmes plus âgés ont plus la possibilité de justifier la violence contre la femme. Les hommes et les femmes dans l'union polygame avaient plus la possibilité d'accepter la violence domestique contre la femme, quoique l'association n'ait pas toujours été remarquable. A part l'Ouganda, Les femmes qui travaillent pour être payées avaient plus la possibilité de justifier la violence contre la femme que celles qui ne travaillent pas. Les résultats ont montré que les normes sociales et culturelles dominantes créent les images des femmes « idéales » chez les hommes et les femmes qui comprennent la définition et l'acceptation très répandue des rôles des femmes et des hommes aussi bien que l'emploi sanctionné de la force pour faire respecter ces rôles. L'Etat et ses diverses institutions manqueront peut-être de réduire la violence contre la femme comme il manquera vraiment la sensibilité d'aborder de manière objective le problème de la violence contre la femme. A travers l'éducation, la croissance économique, l'on peut réduire l'incidence de la violence domestique contre la femme. Le procès sera peut-être lent et trop tard pour faire une différence remarquable dans l'avenir. Il faudra peut-être des dispositifs positifs pour changer des attitudes envers la violence domestique contre la femme chez les hommes et les femmes. (Rev Afr Santé Reprod 2004; 8 [3]:116-136)

KEY WORDS:Wife-beating, Benin, Mali, Rwanda, Malawi, Uganda, Zimbabwe, sub-Sabaran Africa, attitudes, conceptual framework

${ }^{1}$ Manju Rani, 2509 Glenallen Avenue, Apartment 204, Silver Spring, MD 20906. Tel: $3019628979{ }^{2}$ Johns Hopkins Bloomberg School of Public Health, Centre for Communication Programs, Baltimore, MD, US A. Tel:4106596300 E-mail:nsidibe@,jhsph.edu

Correspondence: 2509 Glenallen Avenue, Apartment 204, Silver Spring MD 20906, USA. Tel: +1 301962 8979; E-mail: mrani@jhsph.edu 


\section{Introduction}

In the past few decades, concerns have been increasingly expressed about violence against women, especially intimate partner violence (IPV), in both developed and developing countries.' Gender-based violence has been acknowledged worldwide as a violation of the basic human rights. Researchers have also been documenting the health burden; ${ }^{2-5}$ and adverse intergenerational, demographic and socio-economic consequences of such violence. ${ }^{6-11}$ In addition, as more and more evidence demonstrates the association between intimate partner violence and spread of HIV/AIDS, ${ }^{12}$ addressing issues of status of women, including intimate partner violence, must become an integral part of addressing the HIV/AIDS pandemic.

A troubling aspect of wife-beating is its benign social and cultural acceptance in several parts of the world as a means of physical chastisement of women the husband's right to "correct" an erring wife. ${ }^{17,13}$ Preliminary evidence from Egypt, Brazil, Ghana and Chile suggests that both men and women share the notion of men having a right to discipline their wives by use of force. ${ }^{7}$ Generally, any transgression by women of the prevalent gender norms social norms about the proper roles and responsibilities of men and women is considered a just cause for wife-beating. ${ }^{13}$ If the wife-beating falls within the culturally acceptable limits, others family, community, law enforcement agencies, health providers, etc may not be willing to intervene and may in fact implicitly legitimise such practices. In some extreme cases, the state laws have even legitimised wife-beating the Kenyan law permits husbands to "chastise" their wives. ${ }^{14}$

Though the societal acceptance of wifebeating is believed to be rather widespread in the developing world, the empirical evidence on the extent of acceptance of wife-beating, the circumstances in which wife-beating is acceptable and on the correlates of acceptance of wife-beating is scanty. Most of the studies in the developing countries on wife-beating have focused more on actual prevalence of wifebeating and its determinants ${ }^{15-18}$ and less on the underlying attitudes towards wifebeating. In addition, with the exception of few studies $^{19-20}$, most of the existing studies on wife-beating are based on women's responses, not taking into account the men's perspective.

Knowing the extent and reasons for justification of wife-beating in a particular setting is important for different reasons. First, unfettered social and cultural acceptance of wife-beating may not only lead to abetting such practices, but may also create major obstacles to change such practices. Hence, understanding the underlying attitude towards wife-beating may be fundamental for designing effective programmes to address the issue. Second, acceptance of wife-beating can be a good indicator of the status of women in a specific social and cultural setting, and of various challenges involved in ensuring gender equity. Levels of acceptance of wifebeating can provide insights into the stage of social, cultural and behavioural transformation of a specific society in its evolution towards a more gender egalitarian society.

In the context of sub-Saharan Africa, though there is some documentation of high levels of wife abuse, ${ }_{18,21-24}$ we came across few studies that examined the levels and correlates of acceptance of wife-beating among men and women. Data published based on demographic and health surveys (DHS) from seven sub-Saharan countries, namely, Benin, Ethiopia, Malawi, Mali, Rwanda, Uganda and Zimbabwe, suggest very high levels of acceptance of wife-beating for transgression of gender norms among women. . $^{2531}$ This study will investigate gender differentials in the extent and predictors of acceptance of wife-

IPV encompasses psychological, physical and sexual violence. This study focuses only on

wife-beating, i.e., physical violence 
beating. In specific, the study will examine the effect of different women autonomy indicators such as female literacy, female labour force participation and household decision-making on the attitudes towards wife-beating. In addition, the study will explore whether effect of different enabling factors on attitudes varies among men and women. The study will provide an important cross-country perspective on acceptance of wife-beating among countries with different religious settings and at different stages of development. Lastly, the study attempts to provide a conceptual framework to understand the effect of different enabling factors in changing the attitudes towards gender norms and wife-beating.

\section{Study Setting}

All the seven countries examined are lowincome countries with GNP per capita varying from US $\$ 615$ in Malawi to US $\$ 2635$ in Zimbabwe. All are patriarchal societies characterised by relations of power and authority of males over females. Traditions such as bride price, polygamy, etc, that undermine the status of women are rampant. With the exception of Benin and Zimbabwe, where almost $40 \%$ of population live in urban areas, $70 \%$ of the population lives in rural areas. All countries, with the exception of Zimbabwe, have low female literacy rates. The predominant religion varies from Islam in Mali to Christianity in Ethiopia, Malawi, Uganda and Zimbabwe. Table 1 provides selected socio-demographic characteristics of the countries.

\section{Conceptual Framework and Study Hypotheses}

Studies from different patriarchal societies have identified a common set of role expectations for women preparing food properly, caring for children, seeking husband's or other family member's permission before going out, not arguing with husband, and meeting the sexual needs of the husband. An important 'trigger' for wifebeating in such patriarchal societies is the transgression of established gender roles. Building upon this evidence, a set of statements was used in the DHS surveys to investigate the levels and predictors of acceptance of wife-beating conditional to transgression of gender roles among both men and women.

In essence, assessing acceptance of wife-beating conditional to transgression of gender norms examines two important areas extent of normative acceptance of the specified gender role and of use of violence to enforce that role. Attitudes or norms towards wife-beating or gender role expectations may not be static over time in a society or even during the lifetime of an individual. Different factors may influence the attitude towards wife-beating, resulting in variations in attitudes among individuals in a society.

The conceptual framework (Figure 1) used in this study to understand the predictors of attitude towards wife-beating is based on the social learning theory ${ }^{33}$ and the ecological framework. ${ }^{32}$ Social learning theory postulates that individuals learn how to behave by observing and re-enacting the behaviour of role models. Social norms and gender roles in a patriarchal society are learned within a social group and transmitted from generation to generation. Central to the acceptance of wife-beating is a patriarchal ideology or myth of male superiority. However, some factors at the level of the individual, family, community or the society can intervene to modify the social learning process by allowing individuals to critically question the established norms learned and to challenge those that are not right. We conceptualise that these enabling factors will operate mainly via three mechanisms as presented in Figure 1: by producing a conflict between reality and myth of male superiority; by exposing to more egalitarian social networks and authority structures other than kin-based ones; and by exposing to nonconformist ideas through modern media and 


\section{Table 1 Selected Social, Economic and Demographic Characteristics of the Countries included in the Study}

\begin{tabular}{|c|c|c|c|c|c|c|c|}
\hline Variable & Benin & Ethiopia & Malawi & Mali & Rwanda & Uganda & Zimbabwe \\
\hline$\overline{\text { Urban }(\%)^{\mathrm{a}}}$ & 40.9 & 17.6 & 16.3 & 30.7 & 17.8 & 16.6 & 38.6 \\
\hline \multicolumn{8}{|l|}{ GDP per capita (PPP } \\
\hline International $\$)^{\mathrm{b}}$ & 1030 & 668 & 615 & 780 & 930 & 1208 & 2635 \\
\hline Female illiteracy rate $(\%)^{\mathrm{a}}$ & 64.0 & 75.2 & 23.9 & 80 & 29.4 & 21.9 & 6.7 \\
\hline Female labour force & 430 & 350 & 460 & 440 & 520 & 460 & 410 \\
\hline \multicolumn{8}{|l|}{ Religion $(\%)^{a}$} \\
\hline Christianity & 48.1 & 67.2 & 84.0 & 3.1 & na & 81.8 & 84 \\
\hline Islam & 31.7 & 29.3 & 13.9 & 93 & na & 12.9 & $\mathrm{Na}$ \\
\hline Other religions & 20.2 & 3.5 & 2.1 & 3 & na & 5.3 & 15.8 \\
\hline Polygamy $(\%)^{\mathrm{a}}$ & 28.4 & 8.2 & 11 & 34 & 5.3 & 17.7 & 9.4 \\
\hline
\end{tabular}

Source: ${ }^{a}$ Demographic and health surveys of the concerned countries; and ${ }^{b}$ World Development

Indicator, World Bank, 2002.

The myth of male superiority is maintained in many societies through rigid gender norms and social practices such as polygamy, restriction on movement of women, bride price, etc, and other practices that result in overall lower achievement levels among women including education, employment, financial power, public role, etc. However, as women achieve education, employment and financial capability at par with men, a conflict is produced between reality and notion of male superiority. This may lead women to question the social norms regarding gender roles and wife-beating that support the notion of male superiority. This conflict between reality and myth of male superiority may have effects in either direction among men, at least in the short term. Men may either realise the falseness of the notion of male superiority and adopt more egalitarian attitudes or may resort to use of force to provide the ultimate support for the male dominance. For example, both lower and higher financial contribution by men towards household expenditures may lead to higher acceptance of wife-beating among men. At one end, men who are not contributing sufficiently to the household expenditures may feel frustrated by their inability to fulfil their traditional role of primary provider for the family, and even resort to violence to assert their dominance. ${ }^{15}$ At the other end, men who contribute a major proportion of household expenditures may feel uninhibited due to fiscal dominance to unleash physical violence. Similarly, high women autonomy as measured by household decision-making power should be associated with lower acceptance of wife-beating. Age can influence gender power balance because an individual plays different social roles at different ages.

Some of the enabling factors may expose men and women to ideas and practices not conforming to prevalent social norms. For example, urban residence, education, interaction with outsiders at the work place and migration may expose people to new ideas. Similarly, some of these factors may also expose people to more egalitarian social structures at the work place or at 


\section{Background characteristics}

- Patriarchy

- Gender roles and norms/women's status

- Childhood experience

- Prevalence of wifebeating in the community

- Socio-political and legal settings
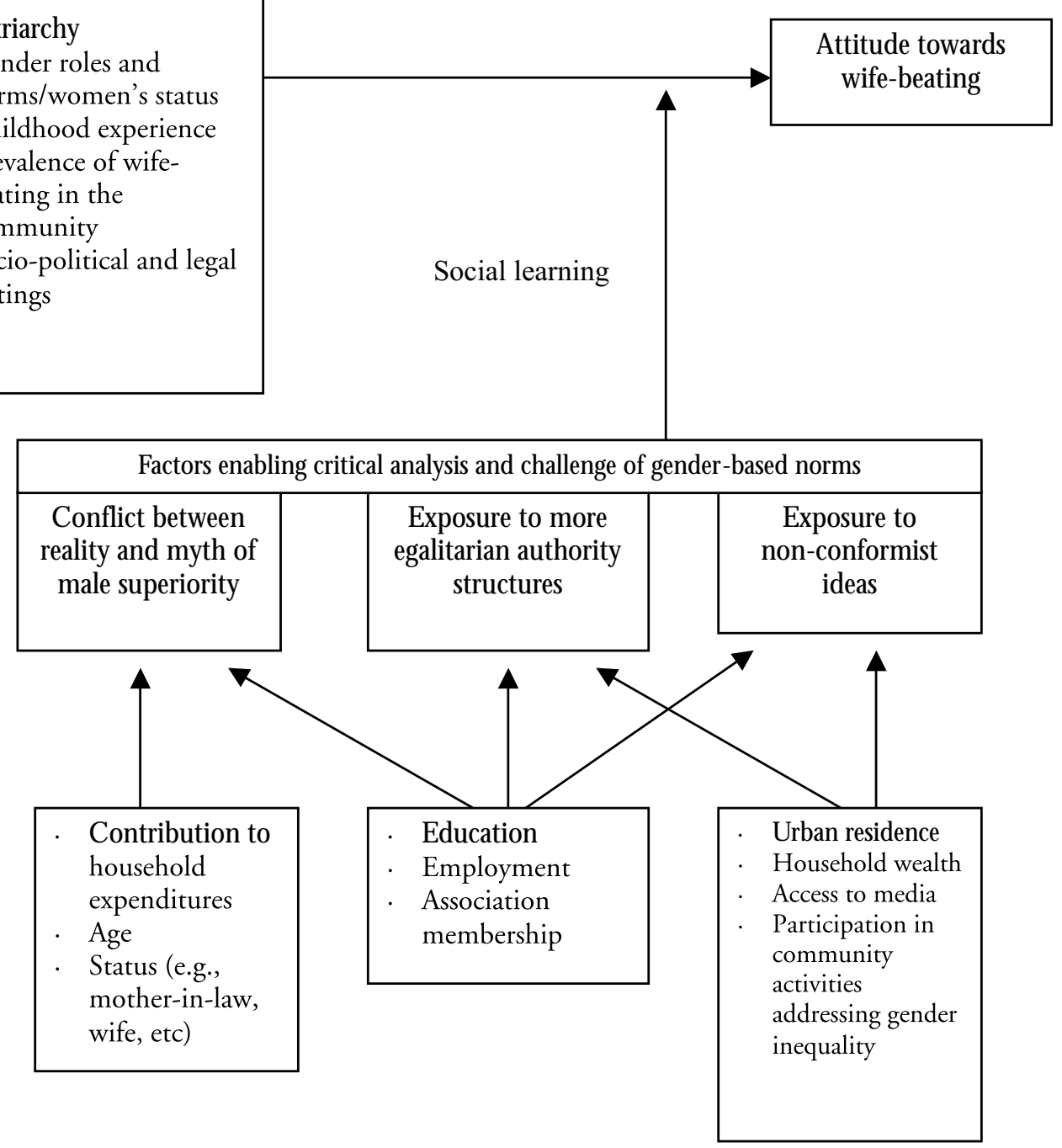

Figure 1 Conceptual Framework for Analysing the Predictors of Acceptance of Wife-Beating and Potential Predictors 
school. Wealth defines class, which may be characterised by different social networks. Poverty may increase chances of conflict over resources, and it is likely that individuals growing up in poorer households and neighbourhoods have more exposure to violence both within and outside the family resulting in higher acceptance of violence among poor people to resolve the conflict.

We hypothesise that in an environment of high compliance with social norms, the effect of the enabling factors on reducing the acceptance of wife-beating will be higher among women than men, at least in the short run, as men may not easily give up their traditional privileges. For example, education and urbanisation will have a greater negative effect on acceptance of wifebeating among women than among men. Unless the enabling factors lead men to recognise the negative consequences and burden imposed by discriminatory gender norms and wife-beating on everyone, men may be slow or resistant to lose their privileges.

\section{Data and Methods}

Data

Data for the study were obtained from the demographic and health surveys (DHS) conducted between 1999 and 2001 as listed in Table 2. DHS surveys are implemented by respective national institutions and Macro International Inc., with financial support from the US Agency for International Development. Selection of the countries in the study was determined by availability of comparable data on attitudes towards wifebeating. DHS data are nationally representative, cross-sectional, household sample surveys with large sample sizes, typically between 5,000 and 15,000 households. The sampling design typically involves selecting and interviewing separately nationally representative probability samples of women aged 15-49 years and men aged 1559 years based on multi-stage cluster sampling, using strata for rural and urban areas and for different regions of the countries. ${ }^{34}$ The survey instruments household questionnaire, women's questionnaire and men's questionnaire are comparable across countries, yielding intercountry comparable data. Table 2 provides the year of survey and sample sizes used for all the

To assess the degree of acceptance of wife-beating by women and men, respondents were asked the following question: "Sometimes a husband is annoyed or angered by things which his wife does. In your opinion, is a husband justified in hitting or beating his wife in the following situations?" The five scenarios presented to the respondents for their opinions were: "if wife burns the food," "if wife argues with the husband," "if wife goes out without informing the husband," "if wife neglects the children," and "if the wife refuses to have sexual relations with the husband".

Information was collected from all women and men irrespective of their marital status except in Zimbabwe, where information was collected only from women. In addition, questionnaires elicited information on the socio-demographic background of respondents and their employment status. 
Table 2 Countries, Survey Years and Sample Sizes for Male and Female Surveys included in the Study

\begin{tabular}{lrrr}
\hline & Year of survey & Sample size (female) & Sample size (male) \\
\hline Benin & 2001 & 6,219 & 2,709 \\
Ethiopia & 2000 & 15,359 & 3,092 \\
Malawi & 2000 & 13,218 & 3,393 \\
Mali & 12,849 & 2,606 \\
Rwanda & 2000 & 10,419 & 2,717 \\
Uganda & 2000 & 7,246 & 1,961 \\
Zimbabwe & 2001 & 5,896 & NA \\
\hline
\end{tabular}

NA $=$ not available

\section{Methods}

A multivariate logistic regression was estimated separately for men and women in each country to assess the independent association of different explanatory characteristics identified in the conceptual framework with the acceptance of wifebeating. A binary outcome variable was created for acceptance of wife-beating, coded as ' 0 ' if the respondent did not agree with any of the situations when a husband is justified in beating the wife or did not have any opinion on the issue and coded as ' 1 ' if the respondent agreed with at least one situation where the husband is justified in beating the wife.

Due to lack of data on the traditional measures of income expenditure or consumption an index of household wealth based on ownership of different household assets was used to measure the socioeconomic status of the household, following the principal component analysis method used by Filmer and Pritchett. ${ }^{35}$ Table 3 provides the definition and specification of the explanatory variables used in the multivariate models. Though similar multivariate logistics models were fitted for each country, data were not available for all the explanatory characteristics in some of the countries. For example, the data on religion were not available for Rwanda and data on household decision-making power were not available in Ethiopia.

All the estimates have been weighted at the national level to provide populationbased representative estimates. In addition, all the estimates and standard errors were adjusted for stratified clustered sampling design. Variables significant at 0.10 level were retained in the final models. 
Table 3 Specification and Definition of the Explanatory Variables included in the Multivariate Logistic Model to Estimate Predictors of Acceptance of Wife-Beating

\begin{tabular}{|c|c|}
\hline Variables & Definition \\
\hline $\operatorname{Urban}(\mathrm{R}=$ rural $)$ & Residence: Rural $=0$; Urban $=1$ \\
\hline Household wealth index & Household wealth index (continuous) \\
\hline \multicolumn{2}{|c|}{ Level of education ( $R=$ no education) } \\
\hline Primary & Incomplete/complete primary $=1$, else $=0$ \\
\hline Secondary & Incomplete/complete secondary $=1 ;$ else $=0$ \\
\hline Higher & Higher than secondary $=1 ;$ else $=0$ \\
\hline \multicolumn{2}{|l|}{ Religion $(\mathrm{R}=\text { Catholic Christians })^{\mathrm{a}}$} \\
\hline Non-Catholic Christian & Non-Catholic Christians $=1$; else $=0$ \\
\hline Muslims & Muslims $=1 ;$ else $=0$ \\
\hline Other & Others $=1 ;$ else $=0$ \\
\hline \multicolumn{2}{|c|}{ Marital status ( $\mathrm{R}=$ married in a monogamous union) } \\
\hline Married in polygamous union & Currently married in polygamous union $=1$; else $=0$ \\
\hline Never married & Never married $=1$, else $=0$ \\
\hline Widowed/divorced/separated & Widowed/divorced/separated $=1 ;$ else $=0$ \\
\hline \multicolumn{2}{|c|}{$\begin{array}{l}\text { Age ( } 3 \text { dummy variables in the model for women, and } 4 \\
\text { dummy variable in the model for men) ( } R=15-19 \text { years) }\end{array}$} \\
\hline $20-29$ years & Age between $20-29$ years $=1$; else $=0$ \\
\hline $30-39$ years & Age between $30-39$ years; else $=0$ \\
\hline $40-49$ years & Age between $40-49$ years; else $=0$ \\
\hline $50-59$ years (only in men) & Age between $50-59$ years; else $=0$ \\
\hline Women's decision making index ${ }^{c}$ & $\begin{array}{l}\text { Number of household decisions on which women has no } \\
\text { control ranging from } 0-5 \text { (continuous) }\end{array}$ \\
\hline \multicolumn{2}{|l|}{ Employment $(\mathrm{R}=\text { not working })^{\mathrm{b}}$} \\
\hline Working but not paid & Working in non-paid employment $=1$; else $=0$ \\
\hline Paid employment & Working in a paid employment $=1$; else $=0$ \\
\hline \multicolumn{2}{|c|}{$\begin{array}{l}\text { Contribution to household expenditure }{ }^{\mathrm{d}} \\
(\mathrm{R}=\text { contributes less than } 50 \%)\end{array}$} \\
\hline Contributes half & Contributes to half of total household expenditure $=1$; else $=0$ \\
\hline Contributes more than half & $\begin{array}{l}\text { Contributes to more than half of total household expenditure }= \\
1: \text { else }=0\end{array}$ \\
\hline
\end{tabular}

Withinparentheses $R=$ reference group

${ }^{a}$ Data on religion not available for $\mathrm{R} w a$ anda.

${ }^{b}$ Data on type of employment not available for men in Ethiopia and in Rwanda.

"The five decision-making areas considered in the construction of index include seeking health care, making large household purchases, making daily household purchases, visiting family/friends, deciding what to cook in the household. The higher the index, the lower is the decision-making power.

'Data on contribution to household expenditure not available for Ethiopia (both men and women) and for men in Rwanda. 
124 African Journal of Reproductive Health

\section{Results}

Univariate results are presented first, followed by results of multivariate logistic regression, separately for men and women.

Justification of Wife-Beating Varied by Gender Norm Transgressed

In general, the patterns of justification for wife-beating by different reasons were similar among men and women within and across countries (Figure 2). With few exceptions, wife-beating was least acceptable if "wife burns the food". Nonetheless, the proportion of respondents who agreed with the statement ranged from $12 \%$ in Zimbabwe to $65 \%$ in Ethiopia among women and from $6 \%$ in
Malawi to $44 \%$ in Ethiopia among men. With few exceptions, the justification for wifebeating was also relatively lower for "refusing sexual relations" among the scenarios presented. The justification for wife-beating for refusing sex ranged from $17 \%$ in Benin to $74 \%$ in Mali among women and from $9 \%$ in Benin to $46 \%$ in Ethiopia among men. An intriguing gender difference was observed in Mali for "refusal to have sex" while $74 \%$ of women justified wife-beating for refusing sex, only $40 \%$ of men said so. Fear of violence for refusing sexual relations may have important implications for the efforts to stall progress of HIV/AIDS epidemic in this region.

"Neglecting the children" was the most common reason agreed to by both women and men for justifying wife-beating, followed by going out without informing husband and arguing back with the husband.

Figure 2 Percentage of Women (W) and Men (M) who Accept Wife-Beating for Different Reasons in Different Countries 
Men were consistently less likely to justify wife-beating than women in all the six countries (Figure 2 and Table 4). While the percentage women who justified wifebeating in at least one of the scenarios ranged from $36 \%$ in Malawi to $89 \% \mathrm{n}$ Mali, the proportion of men who justified wife-beating ranged from $25 \%$ in Malawi to $75 \%$ in Ethiopia. Similarly, the mean number of scenarios out of the five presented in which wife-beating was justified ranged from 0.91 in Malawi to 3.15 in Mali for women, and from 0.54 in Malawi to 2.46 in Ethiopia for men (Table 4). More than three-fourth of women in Mali, Ethiopia and Uganda justified wifebeating for at least one reason. Gender differentials in justification of wife-beating were the most pronounced in Benin.

Results of Multivariate Logistic Regression among Women

Table 5 presents the adjusted odds ratio (OR) for justification of wife-beating. The odds ratio shows the proportional effect on the odds of justification of wife-beating from a unit change in the covariate, when the covariate is continuous. In the case of a categorical covariate, the odds ratio gives the

Table 4 Mean Number of Scenarios out of Five for which Men and Women Justified Wife-Beating in Seven African Countries

\begin{tabular}{|c|c|c|c|c|}
\hline & \multicolumn{2}{|c|}{ Women } & \multicolumn{2}{|c|}{ Men } \\
\hline & Mean number & $\begin{array}{c}95 \% \text { confidence } \\
\text { interval }\end{array}$ & Mean number & $\begin{array}{c}95 \% \text { confidence } \\
\text { interval }\end{array}$ \\
\hline Benin & 1.81 & $1.69-1.92$ & 0.73 & $1.69-1.92$ \\
\hline Ethiopia & 2.97 & $2.87-3.08$ & 2.46 & $2.31-2.61$ \\
\hline Malawi & 0.91 & $0.86-0.96$ & 0.54 & $0.48-0.60$ \\
\hline Mali & 3.15 & $3.05-3.24$ & 1.73 & $1.60-1.86$ \\
\hline Rwanda & 1.60 & $1.54-1.67$ & 0.92 & $0.85-1.00$ \\
\hline Uganda & 2.07 & $1.97-2.17$ & 1.71 & $1.56-1.86$ \\
\hline Zimbabwe & 1.25 & $1.18-1.92$ & NA & NA \\
\hline
\end{tabular}

odds associated with a given category, relative to the odds for the reference category. An odds ratio greater than one implies a positive effect of the covariate on the justification of wifebeating; an odds ratio of less than one indicates a negative effect.

Association with urban residence was not consistent across countries the; no significant association in Ethiopia, Mali and Rwanda, a moderately significant negative association in Uganda $(\mathrm{OR}=0.80, \mathrm{p}<0.10)$ and Zimbabwe $(\mathrm{OR}=0.80, \mathrm{p}<0.10)$, and a more significant negative association in Benin $(\mathrm{OR}=0.61, \mathrm{p}<0.05)$ and Malawi $(\mathrm{OR}=0.53, \mathrm{p}<0.001)$. Women living in likely to justify wife-beating, despite the fact that a substantial proportion of women even in the richest quintile accepted wife-beating for one reason or the other (Figure 3). Though secondary or higher education was negatively associated with wife-beating in all the countries, the effect of primary education was not consistent across countries, a significant negative effect was observed only in Benin and Rwanda, while a positive association was observed in Malawi. Despite a strong and consistent negative effect of secondary wealthier households were consistently less 
126 African Journal of Reproductive Health

education, justification of wife-beating than Catholic respondents in Malawi, while remains relatively high even in this group the relationship was in the opposite direction (Figure 4)

No consistent relationship was seen with religion. Muslim women were significantly less likely to justify wife-beating in Mali and Benin (Table 5). Finally, Zimbabwean women belonging to 'other' religions were likely to justify wife-beating, compared to Catholics.

Figure 3 Percentage of Women who Justified Wife-Beating for at least One of the Reasons by Household Wealth

Figure 4 Percentage of Women who Justified Wife-Beating for at least One of the Reasons by Level of Education 
After controlling for other socioeconomic characteristics, older women were generally less likely to accept wife-beating. However, no statistically significant association with age was observed in high acceptance countries, Ethiopia and Mali. Never married women were significantly less likely to justify wife beating than their married counterparts in monogamous relationships in Ethiopia, Mali, Rwanda and Zimbabwe. The relationship was only weakly significant in Benin and non-significant in Malawi and Uganda. Women married in polygamous relationships were more likely to justify wife-beating, though the relationship was statistically significant only in Mali and Malawi.

Table 5 Multivariate Regression Results Showing Adjusted Odds for Relationship between Acceptance of Wife-Beating and Different Explanatory Variables among Women in Seven sub-Saharan African Countries

\begin{tabular}{|c|c|c|c|c|c|c|c|}
\hline Explanatory characteristic & Benin & Ethiopia & Mali & Malawi & Rwanda & Uganda & Zimbabwe \\
\hline \multicolumn{8}{|l|}{ Residence (rural) } \\
\hline Urban & $0.61 * * *$ & 1.19 & 0.85 & $0.58 * * *$ & $0.85 *$ & $0.80 *$ & $0.80 *$ \\
\hline \multicolumn{8}{|l|}{ Income (continuous) } \\
\hline Household asset index & $0.91 * * *$ & $0.85 * * *$ & $0.94 * * *$ & * $0.93 * * *$ & $0.53 * * *$ & $0.90 * *$ & $0.87 * * *$ \\
\hline \multicolumn{8}{|l|}{ Education (no education) } \\
\hline Primary (no education) & $0.76 * * *$ & 0.85 & 1.15 & $1.15 * *$ & $0.81 * * *$ & 0.97 & 0.94 \\
\hline Secondary & $0.39 * * *$ & $0.42 * * *$ & $0.79 *$ & 0.84 & $0.46 * *$ & 0.82 & $0.76^{*}$ \\
\hline Higher & $0.18^{* * *}$ & $0.06^{* * *}$ & $0.11 * * *$ & $0.07 * *$ & $0.13 * * *$ & $0.44 * * *$ & $0.23 * * *$ \\
\hline \multicolumn{8}{|l|}{ Religion (Catholic) } \\
\hline Non catholic & $1.20^{*}$ & 0.89 & NA & 1.04 & $\mathrm{Na}$ & 0.99 & NA \\
\hline Muslim & $2.29 * * *$ & 0.98 & $2.19 * * *$ & $0.68 * * *$ & $\mathrm{Na}$ & 0.85 & NA \\
\hline Other & 1.04 & 0.73 & 1.49 & 1.22 & $\mathrm{Na}$ & 0.89 & $1.43 * * *$ \\
\hline \multicolumn{8}{|l|}{ Age group (15-19) } \\
\hline $20-29$ & $0.78 * *$ & 1.00 & 0.92 & $0.85^{* *}$ & $0.80 * *$ & 1.08 & $0.66^{* * * *}$ \\
\hline $30-39$ & $0.72 * * *$ & 0.86 & 0.96 & $0.70 * * *$ & $0.79 * *$ & 0.90 & $0.44 * * *$ \\
\hline $40-49$ & $0.74 * *$ & 0.94 & $0.73 *$ & $0.72 * * *$ & 0.90 & $0.77^{*}$ & $0.40 * * *$ \\
\hline \multicolumn{8}{|l|}{$\begin{array}{l}\text { Marital status (monogamous } \\
\text { married) }\end{array}$} \\
\hline Polygamous & 1.10 & 1.26 & $1.25 * *$ & $1.13^{*}$ & 1.13 & 1.06 & 1.05 \\
\hline Never married & $0.82 *$ & $0.73 * * *$ & $0.46^{* * *}$ & 0.92 & $0.74 * * *$ & 0.96 & $0.60 * * *$ \\
\hline Widowed/separated & 1.01 & $0.80 * *$ & 0.99 & 0.91 & 0.92 & 0.99 & 0.88 \\
\hline \multicolumn{8}{|l|}{ Employment (not working) } \\
\hline Unpaid job & $1.94 * * *$ & 0.92 & 1.25 & 1.09 & $1.32 * * *$ & $1.67 * * *$ & $1.38 * *$ \\
\hline Paid job & $1.50 * * *$ & 1.07 & 0.98 & $1.24 * *$ & 1.00 & $0.80 * *$ & 1.13 \\
\hline \multicolumn{8}{|l|}{$\begin{array}{l}\text { Contribution to household } \\
\text { expenditures (less than half) }\end{array}$} \\
\hline Half & 0.88 & $\mathrm{Na}$ & 1.54 & 0.99 & 0.82 & 1.10 & 0.96 \\
\hline More than half & $0.71 * * *$ & $\mathrm{Na}$ & 0.76 & $1.13^{*}$ & 1.00 & $2.24 * * *$ & $1.21 * *$ \\
\hline \multicolumn{8}{|l|}{$\begin{array}{l}\text { Household decision-making } \\
\text { index (continuous) }\end{array}$} \\
\hline No control & 0.97 & $\mathrm{Na}$ & $1.05^{*}$ & 0.98 & $1.05^{* *}$ & $1.08 * * *$ & $1.06^{* *}$ \\
\hline
\end{tabular}




\section{African Journal of Reproductive Health}

Women engaged in unpaid jobs were significantly more likely to justify wifebeating compared to women who were not working, though the relationship was statistically significant in only Benin, Rwanda, Uganda and Zimbabwe. Surprisingly, women working for pay were either more or as likely to justify wife-beating than non-working women. The only exception was Uganda, where women working for pay were significantly less likely to justify wife-beating than non-working women after controlling for other sociodemographic characteristics $(\mathrm{OR}=0.80, \mathrm{p}<$ $0.05)$. Similarly, women who contribute more than $50 \%$ of total household expenses were more likely to justify wife-beating in Malawi, Uganda and Zimbabwe, a significant negative relationship was seen only in Benin $(\mathrm{OR}=0.71, \mathrm{p}<0.001)$.

Lower household decision-making power among women was associated with higher acceptance of wife-beating in Mali, Rwanda, Uganda and Zimbabwe, but no significant association was seen in Benin and Malawi.

To conclude, secondary or higher education and household wealth emerged as the most significant and consistent predictors of non-acceptance of wife-beating. On the other hand, employment status and financial importance in the household did not have consistent and expected relationship across the countries.

Results of Multivariate Logistic Regression among Men

Table 6 presents the adjusted odds ratios for men for predicting the justification of wifebeating in at least one scenario. In contrast to women, where a protective association was observed in some countries, urban men were as likely to justify wife-beating as rural men with no statistically significant association observed in any of the countries. Similar to women, household wealth was negatively associated with acceptance of wife-beating among men, except in Rwanda where the relationship was not statistically significant. Primary education was associated with lower acceptance only in Benin (OR $=0.79, \mathrm{p}<$ $0.05)$ and Uganda $(0.57, \mathrm{p}<0.10)$, while a consistent negative association was seen with secondary or higher education, except in Malawi where the association was not statistically significant. Notwithstanding the negative association with household wealth and secondary education, acceptance still remains unacceptably higher even in these groups (Figure 5 and Figure 6).

Figure 5 Percentage of Men who Justified Wife-Beating for at least One of the Reasons by Household Wealth 


\section{Figure 6 Percentage of Men who Justified Wife-Beating for at least One of the Reasons by Level of Education}

Muslim men were significantly less likely to justify wife-beating than Catholic respondents in Malawi $(\mathrm{OR}=0.62, \mathrm{p}<$ $0.001)$, while the reverse was the case in Ethiopia $(\mathrm{OR}=1.36, \mathrm{p}<0.10)$ and Benin $(\mathrm{OR}=1.35, \mathrm{p}<0.001)$. Finally, Ethiopian men belonging to 'other' religions demonstrated positive associations with acceptance of wife-beating, compared to Catholics.

The relationship with age was similar to that among women. Older men were less likely to accept wife-beating except in Mali and Uganda where no statistically significant association was observed with age. Polygamous men were more likely to justify wife-beating in Malawi and Rwanda, though the association was not significant in other countries. However, no significant association was seen with men in monogamous marriages versus never married men, in contrast to women where never married women were less likely to justify wife-beating.

Men who were working in unpaid jobs were less likely to justify wife-beating in Benin and Uganda. No significant association was observed between justification of wife-beating and men working for pay compared to men not working in the multivariate analysis. Men who contributed more than $50 \%$ of total household expenditure were either as likely to justify wife-beating as men who contributed none or less than $50 \%$ of total household expenditures (Benin and Malawi) or less likely to justify (Mali and Uganda) after controlling for other socio-demographic characteristics. No data were available for Ethiopia and Rwanda. Similarly, men who thought that women should not have decision-making power in household matters 
were more likely to accept wife-beating in Benin and Uganda.

\section{Relationship with Other Characteristics}

In addition to the characteristics already enumerated, association of the justification of wife-beating was assessed with duration of marriage, number and sex-composition of living children, and the sex of the head of household. None of these characteristics showed a significant and consistent relationship in any of the countries included in the study. These variables were excluded from the multivariate models.

Difference in Effect of Explanatory Characteristics in Men and Women

As postulated under the section on conceptual framework, some explanatory characteristics may have different effect among men and women, with men being more resistant to change. Urban residence showed a significant differential effect by gender only in Benin and Uganda, where urban residence had no effect among men but was associated with lower acceptance among women. Similarly, household wealth had significantly more negative effect on women than on men in Malawi, while no statistically significant difference in the effect was seen in other countries. While education was observed to have a significantly more negative effect among women in Benin, it had a more negative effect among men in Uganda.

\section{Discussion}

The study shows that wife-beating is widely accepted under certain circumstances by both men and women in all the countries examined. The acceptance was almost universal in Ethiopia, Mali and Uganda. However, it is not assumed here that the beliefs in the women lead to their abuse and battering by men or that men who accept wife-beating are more likely to be wife abusers. However, women who maintain these beliefs may be at a greater risk of continuous abuse than those who do not. Consequently, they may not make active efforts to oppose violence against them. ${ }^{36}$ Similarly, high normative acceptance among men may make it difficult for them to realise the abuse they perpetuate.

Acceptance was high irrespective of the predominant religion practiced in these countries. The acceptance of wife-beating was lowest in Malawi, which also has the lowest GDP per capita of $\$ 615$ but relatively lower female illiteracy rates (24\%). In addition, though acceptance is relatively higher in countries with high level of female illiteracy (Mali and Ethiopia), the acceptance remains unacceptably high even in countries with higher female literacy rates (Malawi and Zimbabwe).

Is the acceptance of wife-beating declining over time? The use of crosssectional data does not allow us to tease out the difference in cohort effect (changes in attitudes of the same age group over time) and the age effect (change in attitudes with age in the same cohort). However, very high acceptance of wife-beating among the younger generations suggest effective intergenerational transmission of norms that have withstood, surprisingly, the influence of modern media and substantial increase in educational levels over the last few decades. 
Table 6 Multivariate Regression Results Showing Adjusted Odds for Relationship between Acceptance of Wife-Beating and Different Explanatory Variables among Men in Six sub-Saharan African Countries

\begin{tabular}{|c|c|c|c|c|c|c|}
\hline & Benin & Ethiopia & Mali & Malawi & Rwanda & Uganda \\
\hline \multicolumn{7}{|l|}{ Residence (rural) } \\
\hline Urban & 0.93 & 0.74 & 1.14 & 0.95 & 0.75 & 1.39 \\
\hline \multicolumn{7}{|l|}{ Income (continuous) } \\
\hline Household asset index & $0.91^{* *}$ & $0.87 * * *$ & $0.89 * *$ & $0.89 * *$ & 0.94 & $0.84 * * *$ \\
\hline \multicolumn{7}{|l|}{ Education (no education) } \\
\hline Primary (no education) & $0.79 * *$ & 0.97 & 0.83 & 1.08 & 1.09 & $0.57^{*}$ \\
\hline Secondary & $0.61^{* * *}$ & $0.36^{* * *}$ & 0.97 & 1.05 & $0.71^{* *}$ & $0.40^{* * *}$ \\
\hline Higher & $0.33^{* * *}$ & $0.13^{* * *}$ & $0.56^{* * *}$ & 0.33 & $0.27^{* * *}$ & $0.25^{* * *}$ \\
\hline \multicolumn{7}{|l|}{ Religion (Catholic) } \\
\hline Non catholic & 0.81 & $1.43^{*}$ & NA & 0.95 & $\mathrm{Na}$ & $0.77^{*}$ \\
\hline Muslim & $1.35^{* *}$ & $1.36^{*}$ & 1.37 & $0.62^{* * *}$ & $\mathrm{Na}$ & 1.41 \\
\hline Other & 1.03 & $3.92 * * *$ & 1.44 & 0.96 & $\mathrm{Na}$ & 0.82 \\
\hline \multicolumn{7}{|l|}{ Age group (15-19) } \\
\hline $20-29$ & $0.79 *$ & 1.04 & 1.30 & 0.73 & $0.49 * * *$ & 1.15 \\
\hline $30-39$ & 0.83 & $0.59 *$ & 1.18 & $0.54^{* *}$ & $0.52 * * *$ & 0.93 \\
\hline $40-49$ & 0.72 & $0.44^{* * *}$ & 0.86 & $0.61^{* *}$ & $0.46^{* * *}$ & 0.86 \\
\hline $50-59$ & $0.51^{* * *}$ & $0.43^{* * *}$ & 1.17 & $0.41 * * *$ & $0.46^{* * *}$ & 0.65 \\
\hline \multicolumn{7}{|c|}{ Marital status (Monogamous } \\
\hline \multicolumn{7}{|c|}{ married) } \\
\hline Polygamous & 1.09 & 0.89 & 1.18 & $1.75^{* * *}$ & $1.68^{*}$ & 1.35 \\
\hline Never married & 1.2 & 1.23 & $0.79 *$ & 0.96 & 1.17 & 0.76 \\
\hline Widowed/separated & 1.4 & $3.43^{* *}$ & 1.07 & 0.94 & $1.53^{*}$ & 0.68 \\
\hline \multicolumn{7}{|c|}{ Household decision-making } \\
\hline \multicolumn{7}{|l|}{ index (continuous) } \\
\hline No control & $1.12^{* *}$ & $\mathrm{Na}$ & 0.96 & 1.05 & $\mathrm{Na}$ & $1.13^{* *}$ \\
\hline \multicolumn{7}{|l|}{ Employment (not uorking) } \\
\hline Unpaid work & $0.68 *$ & $\mathrm{Na}$ & 0.98 & 0.78 & $\mathrm{Na}$ & $0.52 * * *$ \\
\hline Paid work & 1.00 & $\mathrm{Na}$ & 1.24 & 0.82 & $\mathrm{Na}$ & 0.86 \\
\hline \multicolumn{7}{|c|}{$\begin{array}{l}\text { Contribution to household } \\
\text { expenditures (less than half) }\end{array}$} \\
\hline Half & $1.40 * *$ & $\mathrm{Na}$ & 0.78 & 1.12 & $\mathrm{Na}$ & $0.62 * *$ \\
\hline More than half & 0.89 & $\mathrm{Na}$ & $0.52 * * *$ & 1.25 & $\mathrm{Na}$ & $0.50 * * *$ \\
\hline
\end{tabular}

Data on religion uas not available in Ruxanda; $M=M e n ; W=$ Women

"The 'Other" category includes 'traditional', 'no-religion' or 'animist' depending upon the country

${ }^{b}$ In Zimbabue and Mali, the Christian religion was not broken down into catholic and noncatholic, hence 'Christian' was coded as the reference category

The category in () reflects the reference category; $*_{p}<0.10$; ** $<<0.05$, **** $<0.001$ 


\section{African Journal of Reproductive Health}

Although the results show that the norms about wife-beating and gender roles will change with socio-economic development, increasing urbanisation and better education, the effect will not be substantial and it will be very slow. In most of the countries, the effect of education at the individual level was visible only at the secondary or higher level. The limited or no impact of primary level of education is not surprising, as just having few years of schooling, usually acquired at very young age, may not expose men or women to new non-conformist ideas or may not bring that conflict between reality and myth of male superiority required to challenge the gender norms as postulated under the conceptual framework. In addition, effect of education will depend on whether the education is adaptive or transformative, and how it is used to challenge gender bias or to perpetuate traditional gender norms. ${ }^{37}$ These are the subjects of further research that need to be pursued resolutely to provide evidence for effective policy and programmes to mitigate wife-beating. Currently, secondary education rates among women are very low in these countries and are not likely to improve substantially in near the future to affect social norms on wife-beating in aggregate at the level of population through effects of better education.

Consistent with the findings in other study $^{38}$, the results of this study show that employment or financial independence of women alone will not change their attitude towards wife-beating. As mentioned in the conceptual framework, to explain these contradictory results, one needs to examine the social context, circumstances and motivations for women's participation in the labour force. In many of the low-income countries, most of the women work largely in the informal sector in low paid jobs under very exploitative conditions. In such circumstances, women may be exposed to the same patriarchal social structures at the work place that may further reinforce the myth of male superiority among them.

All the above findings suggest that proactive efforts will be required to break the norms that sustain women's vulnerability in the society besides socio-economic development, and promotion of higher education among both men and women. This study points to some policy and programmes implications.

First, direct concerted efforts from the government, non-governmental organisations and enlightened men and women within the society are necessary to raise awareness about the issue and question the social norms. To change an obnoxious and oppressive social practice such as wifebeating, the first step is to build up a substantial momentum of opposition to such practices. In the countries studied, unless additional efforts are made, building a significant constituency against the practices through urbanisation, socio-economic development or higher levels of education may take decades to show results.

Second, the higher level of acceptance of wife-beating among women compared to men in four out of six countries points to an ominous sign. Accepting and justifying violence against self (women) much more than the perpetuator of violence (men) goes against basic human instincts of survival. It is indeed perplexing, and it may be explained 
only by entrenched social and cultural learning processes that subjugate the position of women in the society, socially and collectively undermine their self-esteem and facilitate romanticisation of the "ideal" gender role of women, which also includes docile acceptance of husband's tyranny, etc.

Third, portraying men as devils and perpetrators of violence will not help. The high prevalence of wife-beating is essentially a symptom of distorted social institutions and social norms affecting both men and women equally. The results of the study strongly suggest the need for programmes that involve both men and women by acknowledging the presence of these norms among them. Reducing the prevalence of wife-beating requires men's as well as women's liberation from the binding cultural stereotypic norms. ${ }^{39}$

Current strategies for addressing domestic violence, developed largely in context of developed countries ${ }^{40}$ recommend involving nurses and other health workers to detect and address gender-based violence, declaring domestic violence a legal crime or involving NGOs. However, government institutions gain personality of the social milieu in which they operate. In an environment of such widespread justification of wife-beating for transgressing gender roles cutting across socio-economic status, these institutions (health, law enforcement, NGOs, etc) may not be immune from the prevalent norms that view wife-beating as a husband's prerogative. A study from South Africa showed that public health nurses experience the same cultural values and, indeed, similar or higher levels of violence as the clients they were expected to counsel and treat. ${ }^{40}$ Similarly, evidence from Bangladesh suggests that both modern (police, credit programmes, etc) and traditional institutions reflect the same cultural norms, and not only justify but also implicitly perpetrate violence against women. ${ }^{17}$ Stories are galore in the developing world where police either held the women guilty or refused to register the complaint about domestic violence. Thus, appropriate legislation, mechanisms to punish offenders, care centres, etc, will best succeed only if a social consensus is built around renegotiation of gender roles and against the use of violence to resolve conflicts. Nevertheless, generation of a new social consensus can be an arduous and slow process. As a starting point, to increase the effectiveness of law enforcement machinery, health workers, NGOs, etc, programmes must work to increase awareness about the unjustness of existing social norms and sensitise different instruments of State and other organisations dealing with the issue.

Finally, challenging the norms may lead to an increase in violence in the short term. Men who contributed less than half of total household expenditures were more likely to justify wife-beating in some of the countries. The differential effect of urbanisation, household wealth and education among women and men with the effect being larger among women as seen in some countries here, may increase the frequency of personal disagreement for a subordinate position for women and hence increase in prevalence of wife-beating in the short term. ${ }^{24}$ This potential negative effect should be kept in mind while evaluating the programmes designed to address wife-beating. 


\section{African Journal of Reproductive Health}

Prevalence of wife-beating and Attitudes that support it may be an indication of deeper malaise in the society. A very high acceptance of wife-beating may suggest high levels of acceptance of violence to resolve any conflict and acceptance of violence as an instrument of retribution in general. This may in turn suggest that interpersonal violence in general, including physical violence against children, may be more common in these societies. However, this issue needs further investigation.

\section{REFERENCES}

1. United Nations. FWCW Platform of Action. Violence against women. Www.un.org/womenwatch/daw/beijing/ platform/violence.htm and gopher: // gopher.un.org/00/conf/fwcw/of f/a--20.en.

2. Diop-Sidibé N. Domestic violence against women in Egypt risk factors and health outcomes of wife-beating. Ph.D. Dissertation, The Johns Hopkins University School of Public Health Baltimore, Maryland, 2001.

3. UNICEF. Domestic violence against women and girls. Innocenti Digest No 6. Innocenti Research Center, Florence, Italy, 2000.

4. World Health Organization. Violence Against Women, A Priority Health Issue. WHO/FRH/WHD/97.8. Geneva:WHO, 1999.

5. Heise L, Pitangui J and Germain A. Violence Against Women: The Hidden Health Burden. Washington DC: The World Bank, 1994.

6. Ellsberg MC, Pena R, Herrera A, Liljestrand J and Winkist A. Candies in hell: domestic violence against women in Nicaragua. Soc Sci Med2000; 51: 1595-1610.
7. Heise L, Ellysberg $\mathrm{M}$ and Gottemoeller $\mathrm{M}$. Ending violence against women. Population Reports No. 11. Baltimore: Johns Hopkins University School of Public Health, 1999.

8. Jejeebhoy SJ. Association between wife-beating and fetal and infant death: Impressions from a survey in rural India. Stud Fam Plann 1998; 29(3): 300-308.

9. MacCulloch C. Domestic Violence. Special report of the Inter-American Development Bank. Washington DC: Inter-American Development Bank, 1997.

10. Rao V and Bloch F. Wife-beating, its causes and its implications for nutrition allocations to children: An economic and anthropological case study of a rural South India community. Washington DC: Policy Research Department, Poverty and Human Resources Division, World Bank, 1993.

11. Martin SL, Moracco KE, Garro J, Tsui AO, Kupper LL, Chase JL and Campbell JC. Domestic violence across generations: findings from northern India. Inter J Epidemiol 2002; 31(3): 560-572.

12. Maman S, Campbell J, Sweat MD and Gielen AC. The intersection of HIV and violence: directions for future research and interventions. Soc SciMed 2000; 50: 459-478.

13. Counts D, Brown JK and Campbell JC (Eds.). Sanctions and Sanctuary: Cultural Perspectives on the Beating of Wives. Boulder: Westview Press, 1992, 268p.

14. Jejeebhoy SJ. Wife-beating in rural India: a husband's right? Econ Pol Wkely 1998; 23(15): 588862.

15. Crowe S. African women still denied their reproductive rights. Lancet 1997; 350(9079): 7-22. 
16. Hindin MJ and Adair LS. Who's at risk? Factors associated with intimate partner violence in the Phillipines. Soc Sci Med2002; 55: 1385-1399.

17. Visaria L. Violence against women: a field study. Econ PolWkely2000; 1742-1751.

18. Schuler SR, Syed MH, Riley AP and Shireen A. Credit programs, patriarchy and men's violence against women in rural Bangladesh. Soc Sci Med 1996; 43: 1729-1742.

19. Deyessa N, Kassaye M, Demeke B and Taffa N. Magnitude, type and outcomes of physical violence against married women in Butajira, southern Ethiopia. Ethiop MedJ 1998; 36: 83-85.

20. Blanc AK, Wolff B, Gage AJ, Ezeh AC, Neema S and Ssekamatte-Ssebuliba J. Negotiating Reproductive Outcomes in Uganda. Calverton MD: Macro International Inc. and Institute of Statistics and Applied Economics, Uganda, 1996.

21. Martin SL, Tsui AO, Maitra Kand Marinshaw R. Domestic violence in Northern India. Amer J Epidemiol 1999; 150(4): 417-426.

22. Armstrong A. Culture and Choice: Lessons from Survivors of Gender Violence in Zimbabwe. Harare: Violence Against Women in Zimbabwe Research Project, 1998.

23. Keye D. Domestic violence among women seeking post-abortion care. Int J Gynecol Obstet 2001; 75(3):323-325.

24. Osakue G, Hilber AM. Women's sexuality and fertility in Nigeria. In: Petchesky R and Judd K (Eds.). Negotiating Reproductive Rights. London: Zed Books Ltd., 1998.

25. Jewkes R, Jonathan L and Penn-Kekana L. Risk factors for domestic violence: findings from a South African cross-sectional study. Soc Sci Med 2002; 55: 1603-1617.
26. Central Statistical Office [Zimbabwe] and Macro International Inc. Zimbabwe Demographic and Health Survey 1999. Calverton, Maryland: Central Statistical Office and Macro International Inc, 2000.

27. Central Statistical Authority [Ethiopia] and ORC Macro. Ethiopia Demographic and Health Survey 2000. Addis Ababa: Central Statistical Authority and ORC Macro, 2001.

28. Cellule de Planification et de Statistique du Ministere de la Sante (CPS/MS), Direction Natioanale de la Statistique et de I'lnformatique (DNSI) et ORC Macro. Enquete demographique et de Sante au Mali 2001. Calverton, Maryland, USA : CPS/MS, DNSI et ORC Macro, 2002.

29. National Statistical Office [Malawi] and ORC Macro. Malawi Demographic and Health Survey 2000. Zomba, Malawi and Calverton, Maryland, USA: National Statistical Office and ORC Macro, 2001.

30. Office National de la Population (ONAPO) [Rwanda] et ORC Macro.Enquete Demographique et de Sante, Rwanda 2000. Kigali, Rwanda et Calverton, Maryland, USA:Ministere de la Sante, Office National de la Population et ORC Macro, 2001.

31. Uganda Bureau of Statistics (UBOS) and ORC Macro Uganda. Demographic and Health Survey 2000-2001. Calverton: UBOS and ORC Macro, 2001.

32. Institut National de la Statistique et de l'Analyse Economique (INSAE) et ORC Macro. 2002. Enquete Demographique et de Sante au Benin. Calverton: INSAE et ORC Macro, 2001.

33. Heise LL. Violence against women: an integrated, ecological framework. Violence Against Women 1998; 4(3): 262-290. 


\section{African Journal of Reproductive Health}

34. Bandura A. Social Learning Theory. Englewood Cliffs: Prentice-Hall, Inc, 1977.

35. Macro International Inc. Sampling Manual. DHS-III Basic Documentation No. 6. Calverton, Maryland, 1996.

36. Filmer D and Pritchett L. Estimating wealth effects without expenditure dataor tears: an application to educational enrollments in states of India. World Bank Policy Research Working Paper No. 1994. Washington DC: Development Economics Research Group (DECRG), The World Bank, 1998.

37. Haj-Yahia MM. Beliefs of Jordanian women about wife-beating. Psychol J Woman Quart 2002; 26: 282-291.
38. Patkar A. Socioeconomic status and female literacy in India. Edu Dev 1995; 15(4): 401-409.

39. Sen P. Enhancing women's choices in responding to domestic violence in Calcutta: a comparison of employment and education. Eur J Dev Res 1999; 11(2): 6586.

40. Straus MA. Sexual inequality, cultural norms and wife-beating. In: Emilio C Viano (Ed.). Victims and Society. Washington DC: Visage Press, 1976.

41. Kim J and Mmatshilo M. Women enjoy punishment: attitudes and experiences of gender-based violence among PHC nurses in rural South Africa. Soc Sci Med 2002; 54: 1243 1254. 